写性に富み良好な結果を得たので報告します。

7. 小览股関節撮影用補助具の試作

長沢弘

（新潟大学医学部附属病院）

8. 頭部撮影具について

III 村 潤

（会津若松逿信診療所）

頭部のX線写真の撮影率が多くなったのは，私達の病 院だけではないでしょう。

枚数む多く，事故等の場合は，固定と方向づけに苦学 する，その他，頭部ステレオ撮影が加わり作業量方倍加 されて来た，ステレオの場合のリスホルム依る黑化度 の不揃いるさる事ながら，カセッテの入れ換えによる位 置と角度の歪が重大な影響を来たす，カセッテの角度と 入れ換えを容易にするのに，橾く簡単な方法を用してい るので紹介する.

四切の入る枠を作り、リスホルムを枠上に載せてカセ ッテだけを人れ換えて使用する。

簡単な道具であるが，頭を動かす事なく何枚加撮影出 来る、特にステレオの場合は, 側面にも正確な角度が保 持出来，良い結果を得て能率的である，誰にであ簡単に 作れて便利である。

\section{9. 骨盤計測器の試作について}

山家 富泰・ ○小林 藤一

(豊栄病院)

川瀬 勇夫・貝沼 修吉

（村上病院）

従来より産科系に括いて骨盤計測撮影法は色々な方法 が考えられ用いられてきた。どの方法もできるだけ正確

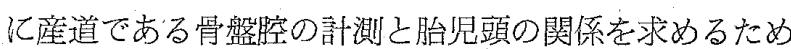
の努力がなされている.

このいず机すが線写真上で計測した香のから真の值 を求めるため，拡大率計算か，金属計算尺を陰裂間にお いて同時撮影して計測する方法が採り入れられている.

てれらは不便であるし，X線写真上にわずかしか軍し込 めない事が岗ったり撮影部位が厚いため，金属計算尺が 読み取り難いととがよくある。

これらの欠点を補い簡便でしかむできるだけ正確に骨 盤腔の阡測子胎览頭の関係が求められ，1放のX線フィ ルム上に必要な高さの目盛を写し込めると計測器を試作 した.

〔結論〕

この計測盤を使用することにより計測盤を恥骨結合又 は聁骨上縁の高さに合わせるだけで非常に簡便に計測で きる。
又, 産科撮影だけでなく, 内科整形外科, 外科等の腫 瘍の大きさを知ることができるし、治療時における位置 ぎめなどにも応用できる面むある．更に $\mathrm{pb}$ 板を取り去 ってアクリル板を利用することにより搪大撮影飞も応用 できます。

最後に一言付ら加えさせて頂きますが，私達はまだ経 験が浅く，私達の見るX線撮影技術書の中には，ての方 法は見当りませんでした。何む知らずに作成し演題を提 出した訳ですが, 最近になって産科学の著書の中にト一 マス氏が，又横浜愛児センターの佣山氏が本法による計 測法を載せているてとを知りました。困って下村会長に 相談したところ，日む迫っているととだから急に取り消 しにするよりむしろ折角考えたあのだからそのまま発 表して，正直にその旨を付け加える上うにとの指示を受 けましたのであえて発表したような次第です。

\section{0. 各種ファントームの比較について}

鐮田 充郎・ “相沢 正明 今岡 淳一・ O桜庭 昇一

（青森県立中央病院）

JIS 規格によるX線用水ファントムを作成しとのファ ントムを従来より当院で使用していた水ファントム及び 人体ファントムの 3 種につけて, ファントム中心より 1 $\mathrm{m}$ の点で $45^{\circ}$ 間隔で 8 ケ所の点の散乱線圭測定した.

結果はJIS ファントムは従来の水ファントムよりあ人 体と非常に近い測定值が得られました。これは，形状が 人体ファントムと同様の円筒形をしているためと思われ ます。それれ比較し，旧ファントムはJIS ファントム及 び人体ファントムより非常に少ない測定値が出ました， ただし測定值の方向性についてそれほど差異はなく，測 定値の数值が問題であると思われます。

\section{X線装置の出力比較測定}

畑山、崇・三浦 涛雄

寺田 保正・三浦 初男 (秋田大学附属病院 放射線科)

[目的]

血管連続撮影装置（三相12パルス）二台の設定管電圧 及び設定管電流に対するX線曝射時の管電圧・管電流の 特性変化, 又整流波形の歪・投入位相, タイマーの誤差 等を検討しX線出力の比較を試みた。

〔結果〕

正面用管電圧 $\pm 10 \%$ 以上，管電流一 $-30 \%$ 側面て管電圧 $\pm 5 \%$ 管電流一 $-20 \%$ 之正面の方が誤差が大きい。 タイ、 一の誤差は $0.1<\mathrm{T} \cdots \cdots \pm 10 \%$ 上内であるが，側面用の 方が $4 \%$ 程長い. 又投入位相のづれ，整流波形の歪も正 